\title{
A study on the relationship of e-marketing, e-CRM, and e-loyalty: Evidence from Indonesia
}

\author{
Ipang Sasono $^{a^{*}}$, Suroso $^{a}$ and Dewiana Novitasari ${ }^{b}$
}

\author{
${ }^{a}$ STMIK Insan Pembangunan, Indonesia \\ CH R O N I C L E \\ Article history: \\ Received: September 20, 2020 \\ Received in revised format: \\ January 15, 2021 \\ Accepted: January 16, 2021 \\ Available online: January 16, 2021 \\ Keywords: \\ E-CRM \\ e-loyalty \\ e-marketing \\ Website
}

${ }^{b}$ Sekolah Tinggi Ilmu Ekonomi Insan Pembangunan, Indonesia

\begin{abstract}
A B S T R A C T
The number of website visits is an important issue in the era of industrial revolution 4.0 for the manufacturing industry of Refrigeration and HVAC (heating, ventilation, and air-conditioning) as an effort in obtaining and maintaining customers. Therefore, e-loyalty is needed to improve the number of website visits. Research is done to test the influence given by e-marketing and e-CRM towards e-loyalty of a website owned by one of the Refrigeration and HVAC (RHVAC) companies in Indonesia. data is collected by a simple random sampling method obtained from 170 respondents of website visitors in the RHVAC fair Indonesia 2018. The method used in this research is multiple linear regression with SEM through the help of SmartPLS 3.0 software. The analysis result of this research shows that e-marketing and e-CRM have a positive and significant effect on e-loyalty, both individually and simultaneously.
\end{abstract}

\section{Introduction}

The fact which shows that internet users keep on increasing in the last 15 years and it has been predicted that the number of internet users will still be increasing until the year of 2015, making the marketing of communication companies pay more attention to existing potential in cyberspace or the internet. The company uses the internet to easily reach out to customers and to manage their relationships with customers. This matter is sure will effectively work out with more of the number of website visitors. With average visit rates of 103 times every day, it turns out that this has not made the company feel that the website is working effectively. The method that could be used in making a close relationship between the company and consumers is by using CRM (Customer Relationship Management), in which by using this method, the customers will feel more understood by the company or the business unit. CRM in nowadays' computer era has developed and improved its feature into E-CRM (Electronic Customer Relationship Management), where the function of CRM is not only as an application used as a call center or a help desk, but also used as a marketing application and as a link between the company and every one of the customers and this also used by the company to improve e-loyalty of the website. With average visit rates of 103 times every day, it turns out that this has not made the company feel that the website is working effectively. The company wants to improve the visit rates, so research to discover the influence given by e-marketing and e-CRM in a company's website towards e-loyalty is needed, where one of the main indicators is revisited by the internet users. By knowing the influence of both factors, the result of research can be made as a managerial input for the company to help in improving the e-loyalty of the website.

\section{Literature review and hypothesis development}

E-marketing is the use of information technology in the process of creating, communicating, and delivering value towards customers, and also can be used to maintain the relationship with customers for mutual benefit (Salehi et al., 2012). The 
company should consider the opportunity of electronic marketing; therefore, the company should discover how to create an interesting website (Kotler \& Lee, 2008). Research is done by Hur et al. (2011) regarding the relationship between sports website quality, e-satisfaction and e-loyalty conclude that sport's team website, which is the non-e-commerce website, has a small possibility of loyalty due to positive perception of the sport's fans and satisfaction of website obtained from the website quality itself. Therefore, a website, as an e-marketing tool, should have better quality and satisfy the users to gain loyalty. 13 criteria can be used to evaluate a website (Selim, 2012). Three of the criteria used in this research is accessibility (the level of access of a website), currency/timeliness that is related to some of the updates in the website, and also accuracy/credibility (which is how factual and verifiable the information and materials provided by the website). The use of 3 criteria in this research is suitable to investigate the company's website that is not too complex, which is an e-marketing media in the form of information regarding service products and another promo without enclosing the e-commerce application. In other words, the company's website does not serve online transactions.

If e-marketing is the process of delivering values to customers, then e-CRM is the system used to maintain the delivered value. E-CRM is a management of a relationship with customers held electronically (Turban et al., 2002). E-CRM is the use of digital communication technology to maximize the relationship between the business and existing customers and keep pushing the use of online services (Chaffey et al., 2019). Based on the definition above, the presence of e-CRM in the website should result in continuous use of the website (Sasono \& Usino, 2018). The implementation of e-CRM is expected to result in a significant value towards the company and customers when people connect (Jih \& Lee, 2012). Therefore, with the increasing use of internet users, then e-CRM is the appropriate solution for the company to maintain its relationship with customers. In this research, e-CRM is measured with 3 dimensions, which consist of information quality, customer service efficiency, and ease of navigation (Hamid et al., 2011).

E-loyalty is the expansion of the conventional loyalty concept applied online (Ghane et al., 2011). E-loyalty is the intention to revisit a particular website, through both online transactions and non-online transactions (Hur et al., 2011). Therefore, since the company's website is non-e-commerce (unable to serve online transactions), then e-loyalty is measured using 3 from 4 indicators without involving action in this research, which consist of cognitive, affective, and conative with each of the indicators, which are the preference, positive attitudes, and revisit (Hur et al., 2011). This research has analyzed the role of the influence of e-marketing and e-CRM towards e-loyalty. Figure 1 shows the framework concept that explains the relationship between each variable.

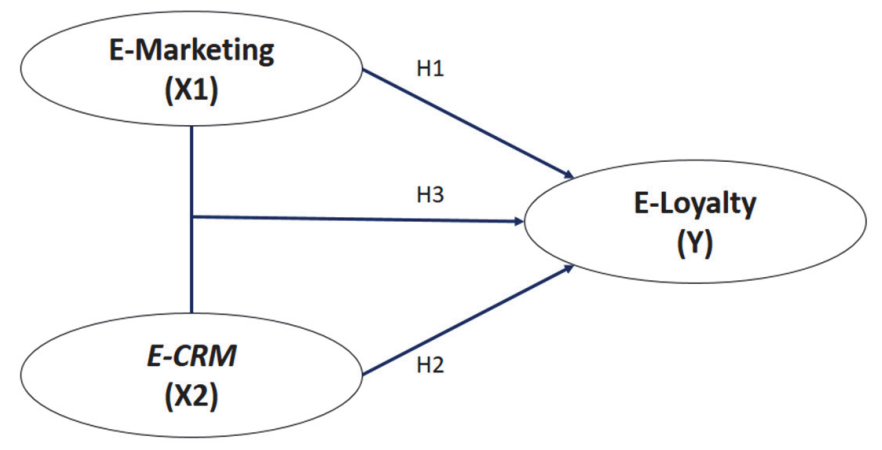

Fig. 1. Concept Framework

Based on the previous empirical studies, then the conclusion can be made as follows:

$\mathrm{H}_{1}$ : E-marketing has a positive significant influence on e-loyalty.

$\mathrm{H}_{2}$ : E-CRM has a positive significant influence on e-loyalty.

$\mathrm{H}_{3}$ : E-marketing and E-CRM have a positive significant influence simultaneously on e-loyalty.

\section{Method}

\subsection{Designing of Research}

The type of research used in the data analysis is explanatory-associative with the research survey method through spreading of questionnaires. The unit of analysis is the visitor or website users in a marketing communication company with a time horizon cross-sectional. Explanatory research is the use of existing data to explain the causal relationship between variables through hypothesis tests; while associative is the explanatory research that tests for a relationship between two or more variables (Sugiyono, 2013). The survey method used to collect data is in the form of the statement, which is then changed to be quantitative data on a Likert scale. The spreading of the questionnaire is done in a Refrigeration \& HVAC Indonesia 2018 fair, which is one of the fairs of the largest refrigeration and HVAC equipment chain industry in Southeast Asia. 
Based on the conceptual research framework and mapping in Fig. 1, variable indicators are obtained. Variable indicators are adopted from previous research, as well as some modifications on those indicators, so operational variables can be defined as follows: (1) E-marketing. E-marketing is the use of information technology in the process of creating, communicating, and delivering value towards customers, and also can be used to maintain the relationship with customers for mutual benefit (Salehi et al., 2012). E-marketing is measured based on indicators adapted from (Prasetya \& So, 2014). There are ten items used in this research, which consist of X1.1-X1.10: "Website publishes the company's visualization and information about service product", "Website ease the customers in contacting the company through a variety of applications", etc. (2) E-CRM. E-CRM is the use of digital communication technology to maximize the relationship between the business and existing customers and keep pushing the use of online services (Chaffey, 2009). E-CRM is measured based on indicators adapted from (Prasetya \& So, 2014). There are 13 items used in this research, which consist of X2.1-X2.13: "Existing information in the website corresponds and related with the company's service product", "website has customer service that responds to customer's questions professionally", etc. (3) E-loyalty. E-loyalty is the intention to revisit a particular website, through both online transactions and non-online transactions (Hur et al., 2011). E-loyalty is a measure based on indicators adapted from (Prasetya \& So, 2014). There are five items used in this research, which are Y1-Y5: "this company's website is more preferable than other company's websites", "willing to revisit the company's website as the source of information regarding products and service of the company", etc. The questionnaire is closely designed, except for the questions/statements concerning the respondent's identity, which is a semi-opened questionnaire. For every closed questions/statement, five answer options are given in Likert scale, which consist of: strongly agree (SA) with 5 scores, agree (A) with 4 scores, Neutral (N) with 3 scores, disagree (DA) with 2 scores, and strongly disagree (SDA) with 1 score. The method in data processing is by using PLS and SmartPLS 3.0 software as the tool.

\subsection{Population and Sample}

The total population of this research is sourced from the total number of website visitors in event of the Refrigeration and HVAC Indonesia 2018 fair, which was held on 26-28 September 2018. A simple random sampling method is used in this research since the population is considered to be homogeneous. From the total visitors in three days of fair, 267 population is obtained. The questionnaire that was returned and valid has the amount of 170 people/questionnaire. Therefore, the sample in this research has 170 samples (63.7\% from the whole population).

\section{Results and discussion}

\subsection{Sample Description}

Respondents' characteristics are seen from their gender, age, and the tools used to access the company website. As shown in Table 1, the highest respondent percentage is female (57\%), in the age of between $20-25$ years old (45\%), and the tools used to access the website is dominated by smartphones $(67 \%)$.

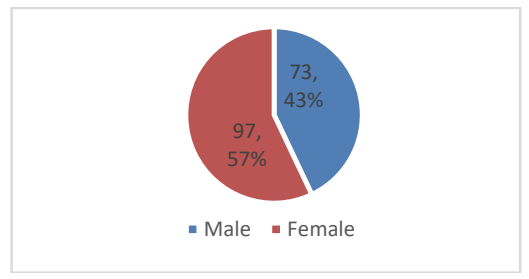

Gender

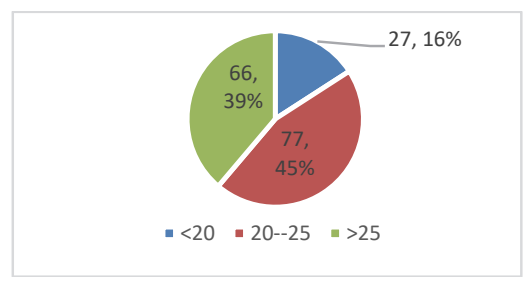

Age (per September 2018)

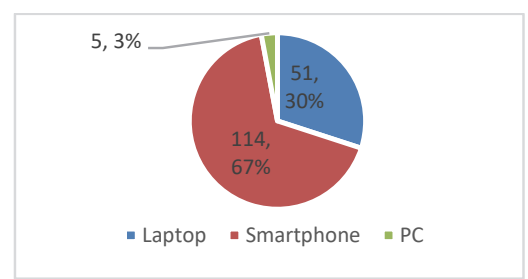

Tools to access the website

Fig. 2. Descriptive Sample Information

Source: The respondent profile table is derived from a summary of the questionnaire returned (authors, 2021)

\subsection{Results for Validity Test and Research Indicator Reliability}

Stages of measuring on testing models involve convergent validity tests and discriminant validity. While the value of Cronbach's alpha and composite reliability is needed in testing for construction reliability. PLS analysis results could be used to test a research hypothesis if all indicators in the PLS model have met the requirements of convergent validity, discriminant validity, and reliability test.

\section{Convergent Validity Testing}

A convergent validity test is done by seeing the value of the loading factor of each indicator towards the construct. In most references, a factor weighing from at least 0.5 is considered to have validity that is strong enough to explain the latent construct (Chin, 1998; Ghozali, 2014; Hair et al., 2010). In this research, the minimum limit of loading factor that is accepted is 0.5 , 
with the condition of AVE score for every construct, which is $>0.5$ (Ghozali, 2014). Based on the data processing result in SmartPLS 3.0, all indicators have a loading factor value above 0.5. Therefore, the convergent validity of this research model has met the requirements. Loading factors, Cronbach's alpha, composite reliability, and AVE in every construct can be seen in Table 1 below:

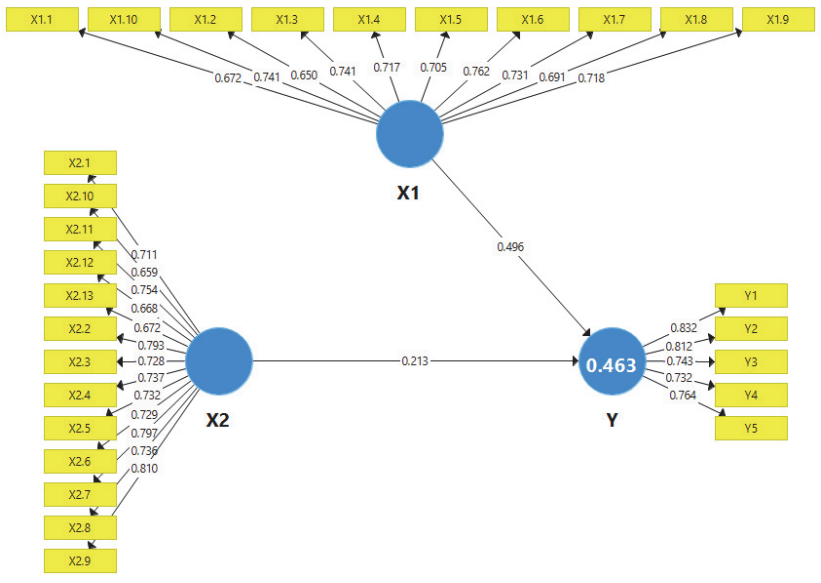

\section{Table 1}

Fig. 3. Model Fit

Items Loadings, Cronbach's Alpha, Composite Reliability, and Average Variance Extracted (AVE)

\begin{tabular}{|c|c|c|c|c|c|}
\hline Variables & Items & Loadings & Cronbach's Alpha & Composite Reliability & AVE \\
\hline \multirow{10}{*}{ e-Marketing (X1) } & $\mathrm{X} 1.1$ & 0.672 & \multirow{10}{*}{0.892} & \multirow{10}{*}{0.912} & \multirow{10}{*}{0.509} \\
\hline & $\mathrm{X} 1.2$ & 0.650 & & & \\
\hline & $\mathrm{X} 1.3$ & 0.741 & & & \\
\hline & $\mathrm{X} 1.4$ & 0.717 & & & \\
\hline & $\mathrm{X} 1.5$ & 0.705 & & & \\
\hline & X1.6 & 0.762 & & & \\
\hline & $\mathrm{X} 1.7$ & 0.731 & & & \\
\hline & $\mathrm{X} 1.8$ & 0.691 & & & \\
\hline & X1.9 & 0.718 & & & \\
\hline & $\mathrm{X} 1.10$ & 0.672 & & & \\
\hline \multirow[t]{13}{*}{ e-CRM (X2) } & X2.1 & 0.711 & \multirow[t]{13}{*}{0.929} & \multirow[t]{13}{*}{0.938} & \multirow[t]{13}{*}{0.539} \\
\hline & $\mathrm{X} 2.2$ & 0.793 & & & \\
\hline & $\mathrm{X} 2.3$ & 0.728 & & & \\
\hline & $\mathrm{X} 2.4$ & 0.737 & & & \\
\hline & $\mathrm{X} 2.5$ & 0.732 & & & \\
\hline & $\mathrm{X} 2.6$ & 0.729 & & & \\
\hline & $\mathrm{X} 2.7$ & 0.797 & & & \\
\hline & $\mathrm{X} 2.8$ & 0.736 & & & \\
\hline & X2.9 & 0.810 & & & \\
\hline & $\mathrm{X} 2.10$ & 0.659 & & & \\
\hline & $\mathrm{X} 2.11$ & 0.754 & & & \\
\hline & $\mathrm{X} 2.12$ & 0.668 & & & \\
\hline & $\mathrm{X} 2.13$ & 0.672 & & & \\
\hline \multirow{5}{*}{ e-Loyalty (Y) } & Y1 & 0.764 & \multirow[t]{5}{*}{0.836} & \multirow[t]{5}{*}{0.884} & \multirow[t]{5}{*}{0.605} \\
\hline & Y2 & 0.717 & & & \\
\hline & $\mathrm{Y} 3$ & 0.900 & & & \\
\hline & Y4 & 0.801 & & & \\
\hline & Y5 & 0.824 & & & \\
\hline
\end{tabular}

Source: The Table is derived from the output of the SmartPLS 3.0 (authors, 2021)

\section{Discriminant Validity Test}

Discriminant validity is done to ensure that every concept of each latent variable is in contrast with the other latent variables. A model has a good discriminant validity if the quadratic value of AVE in each exogenous construct (value on the diagonal) exceeds the correlation between the construct with the other construct (value below diagonal) (Ghozali, 2014). The result of discriminant validity research is done by the quadratic value of AVE, which means by seeing the Fornell-Larcker Criterion Value that is mentioned in Table 2.

\section{Table 2}

Discriminant Validity

\begin{tabular}{|c|c|c|c|}
\hline Variables & X1 & $\mathbf{X 2}$ & $\mathbf{Y}$ \\
\hline e-Marketing (X1) & 0.813 & & \\
\hline e-CRM (X2) & 0.811 & 0.834 & \\
\hline e-Loyalty (Y) & 0.669 & 0.615 & 0.878 \\
\hline
\end{tabular}

Source: The Table is derived from the output of the SmartPLS 3.0 (authors, 2021) 
The discriminant validity test result shown in Table 3 above indicates the whole construct having a square root value of AVE above correlation value with the other latent construct (through Fornell-Larcker Criterion). Likewise, the cross-loading value of all items from another indicator as mentioned in Table 4, so it can be concluded that a model has met a discriminant validity (Fornell \& Larcker, 1981).

\section{Construct Reliability Test}

Construct reliability can be assessed from the value of Cronbach's alpha and composite reliability from each construct. The value of composite reliability and Cronbach's alpha is suggested to be more than 0.7 (Ghozali, 2014). Reliability test results in Table 2 above shows that all constructs have composite reliability value and Cronbach's alpha value higher than 0.7 ( $>$ $0.7)$. In conclusion, all constructs have met the reliability that is required.

\section{Hypothesis Examination}

The hypothesis test in PLS is also denoted as an inner model test. This test covers a significance test that has a direct and indirect impact as well as how large is the measurement of the exogenous variable impact towards the endogenous variable. To discover the influence of e-service quality towards e-satisfaction and e-loyalty, it needs a direct impact test. The direct impact test is done by using the T-Statistic test in an analysis model called Partial Least Squared (PLS) with the help of SmartPLS 3.0 software. With the bootstrapping technique, R square value and significance test value can be obtained as shown in Table 3 below:

Table 3

$R$ Square Value

\begin{tabular}{|c|c|c|}
\hline 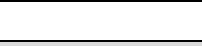 & R Square & R Square Adjusted \\
\hline e-Loyalty (Y) & 0.463 & 0.456 \\
\hline
\end{tabular}

Table 4

Hypotheses Testing

\begin{tabular}{lccccc}
\hline Relationship & Beta & SE & T Statistics & P-Values & Decision \\
\hline $\mathrm{X} 1 \rightarrow \mathrm{Y}$ & 0.496 & 0.094 & 5.289 & 0.000 & Supported \\
$\mathrm{X} 2 \rightarrow \mathrm{Y}$ & 0.213 & 0.098 & 2.176 & 0.030 & Supported \\
\hline
\end{tabular}

Source: The Table is derived from the output of the SmartPLS 3.0 (authors, 2021)

Based on Table 3 above, the R Square value of e-loyalty (Y) is 0.463 , which means that variable e-loyalty (Y) can be explained by variables of e-marketing (X1) and e-CRM (X2) in the percentage of $46.3 \%$, while the remaining $53.7 \%$ is explained by other variables not discussed in this research. Meanwhile, Table 4 shows T-statistics and P-values that explain the influence between variables in the research mentioned previously.

\section{Discussion}

Discussion of the hypothesis is done based on the analysis result shown in Table 4, where the result is obtained as follows: first, based on the first hypothesis (H1), Table 4 shows that significance level of T-test for the hypothesis of influence in emarketing (X1) variable towards e-loyalty (Y) has the value of 0.000 , which is smaller than 0.05 , the t-statistics value of 5.289 that is larger than 1.96 and positive regression coefficient of 1.496 . This explains that $\mathrm{H} 1$ is accepted, which means that e-marketing has a significant positive influence on e-loyalty. This positive influence provides meaning that the increase in emarketing would increase the e-loyalty of website visitors in the HVAC industry in Indonesia. Secondly, based on the second hypothesis (H2), table 5 shows that the significance level of the T-test for the hypothesis of influence in e-CRM (X2) variable towards e-loyalty $(\mathrm{Y})$ has the value of 0.03 , which is smaller than 0.05 , the t-statistics value of 2.176 that is larger than 1.96 and positive regression coefficient of 0.213 . This explains that $\mathrm{H} 2$ is accepted, which means that e-CRM has a significant positive influence on e-loyalty. This positive influence provides meaning that the increase in e-CRM would increase the eloyalty of website visitors in the HVAC industry in Indonesia. Thirdly, based on the third hypothesis (H3), table 4 and table 5 shows that E-marketing and E-CRM have a significant positive influence on e-loyalty. This explains that H3 is accepted. This positive influence provides meaning that simultaneously, e-marketing and e-CRM provides influence contribution as much as $31.6 \%$ with e-marketing as a variable that gives dominant influence from the website visitor in the HVAC industry in Indonesia.

\section{Conclusions and limitations}

The conclusion of this research is based on data analysis results and discussion is done to put forward as follows: (1) Emarketing has a significant positive influence on e-loyalty. This means that the increase in e-marketing would increase the e- 
loyalty of customers in the HVAC industry in Indonesia. (2) E-CRM has a significant positive influence on e-loyalty. This means that the increase in e-CRM would increase the e-loyalty of website visitors in the HVAC industry in Indonesia. (3) Finally, this research concludes that the role of E-marketing and E-CRM has a significant positive influence simultaneously towards e-loyalty of website visitors in the HVAC industry in Indonesia. This result of research claims that e-loyalty of marketing communication company's website has a relationship as well as influenced by e-marketing and e-CRM. The company could increase the number of visitors to the website through e-loyalty that is influenced by e-marketing and e-CRM by paying attention to the indicators.

This research has some limitations. Firstly, this research analyzes the influence of e-marketing and e-CRM on e-loyalty, both directly and at the same time. This is maybe because there are some other variables (such as motivation, belief, company branding, e-trust, etc.) that influence e-loyalty. The author recommends to put forward, explore, analyze in further studies. Secondly, this research is done in the analysis unit of college students in a particular university, which may not be generalized to other industries. Therefore, it is advisable to do further research on this topic in other industries or even adding to all regions or other countries, and comparison between private and public organizations. Some factors that should be noticed by the company regarding the related variables are most website users feel that the existing information in the website cannot completely be used in the accessing period and the URL (link address) of the website is difficult to be remembered and the readiness to revisit a website has the lowest value between all factors that have been researched. Therefore, to raise the user's readiness to revisit a website, the company should pay attention to providing beneficial information for the users and also adding a brief tutorial for the users that feel difficulty in using the website.

\section{References}

Chaffey, D., Edmundson-Bird, D., \& Hemphill, T. (2019). Digital business and e-commerce management. Pearson UK.

Chin, W. (1998). The Partial Least Squares Approach to Structural Equation Modeling (E. Modern Methods for Business Research, In: G. A. Marcoulides (ed.)). Lawrence Erlbaum Associates Publisher.

Fornell, C., \& Larcker, D. F. (1981). Evaluating Structural Equation Models with Unobservable Variables and Measurement Error. Journal of Marketing Research, 18(1), 39. https://doi.org/10.2307/3151312

Ghane, S., Fathian, M., \& Gholamian, M. R. (2011). Full relationship among e-satisfaction, e-trust, e-service quality, and eloyalty: The case of Iran e-banking. Journal of Theoretical and Applied Information Technology, 33(1), 1-6.

Ghozali, I. (2014). Structural Equation Modeling, Metode Alternatif dengan Partial Least Square (PLS) (4th ed.). Badan Penerbit Universitas Diponegoro.

Hair, J. F., Black, W. C., Babin, B. J., \& Anderson, R. E. (2010). Multivariate Data Analysis (7th ed.). Pearson Prentice Hall.

Hamid, N. R., Cheng, A. Y., \& Akhir, R. M. (2011). Dimensions of E-CRM: an empirical study on hotels' web sites. Journal of Southeast Asian Research, 2011, c1-15.

Hur, Y., Ko, Y. J., \& Valacich, J. (2011). A structural model of the relationships between sport website quality, e-satisfaction, and e-loyalty. Journal of Sport Management, 25(5), 458-473.

Jih, W.-J., \& Lee, S.-F. (2012). Effects of e-CRM value perceptions on website loyalty: an empirical investigation from customer perspective. In Transformations in E-Business Technologies and Commerce: Emerging Impacts (pp. 79-92). IGI Global.

Kotler, P., \& Lee, N. (2008). Social marketing: Influencing behaviors for good. Sage.

Prasetya, F., \& So, I. (2014). Pengaruh E-Marketing dan E-CRM terhadap E-Loyalty Website Usaha Komunikasi Pemasaran. Binus Business Review, 5(1), 8-17.

Salehi, M., Mirzaei, H., Aghaei, M., \& Abyari, M. (2012). Dissimilarity of E-marketing VS traditional marketing. International Journal of Academic Research in Business and Social Sciences, 2(1), 510.

Sasono, I., \& Usino, W. (2018). Prototipe Sales Force Automation (SFA) untuk E-CRM di Industri Manufacturing dengan Pendekatan Metodologi Lean Six Sigma. Insan Pembangunan Sistem Informasi Dan Komputer (IPSIKOM), 4(1), 1-12. http://ojs.ipem.ecampus.id/ojs_ipem/index.php/stmik-ipem/article/viewFile/61/60

Selim, H. M. (2012). Content evaluation criteria for general websites: Analysis and comparison. International Journal of Online Marketing (IJOM), 2(3), 21-38.

Sugiyono. (2013). Metode Penelitian Pendidikan Pendekatan Kuantitaif, Kualitatif, dan R\&D. In Metode Penelitian Pendidikan Pendekatan Kuantitaif, Kualitatif, dan R\&D. https://doi.org/10.1007/s13398-014-0173-7.2

Turban, E., King, D., Lee, J., \& Viehland, D. (2002). Electronic commerce: A managerial perspective 2002. Prentice Hall: ISBN 0, 13(975285), 4.

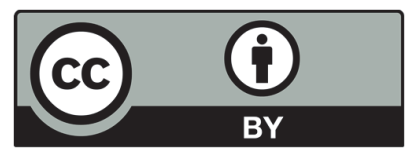

(C) 2021 by the authors; licensee Growing Science, Canada. This is an open access article distributed under the terms and conditions of the Creative Commons Attribution (CC-BY) license (http://creativecommons.org/licenses/by/4.0/). 